\title{
Designation of the Type Strain of Lactobacillus viridescens Niven and Evans
}

\author{
ERWIN F. LESSEL and MORRISON ROGOSA \\ American Type Culture Collection, Rockville, Maryland, \\ and the National Institute of Dental Research, National Institutes \\ of Health, Bethesda, Maryland 20014
}

\begin{abstract}
ATCC 12706 (strain S38A of Niven and Evans) is designated as the type strain of Lactobacillus viridescens Niven and Evans. A description of this strain is also given.
\end{abstract}

Niven and Evans (6) described a new bacterium and proposed the name Lactobacillus viridescens for it. These authors cited S38A as a "typical strain of this new species. ..," but this does not constitute designation of the type strain. Sneath and Skerman (8) listed S38A as a "paratype," which they define as "any strain (other than holotype) which is specifically stated to be one on which the original description of the taxon was based," but again this does not constitute designation of the type strain of $L$. viridescens. Consequently, ATCC 12706, strain S38A of Niven and Evans, is here designated as the type strain of $L$. viridescens Niven and Evans. This strain was isolated from cured meat products, and it is one of the strains on which the original description of $L$. viridescens was based. The characters of this strain, which agree with those recorded in the original description (6) of $L$. viridescens, are as follows.

Small, gram-positive rods, 0.8 by 2.0 to 4.0 $\mu \mathrm{m}$, which may be coccoid; occur singly or in pairs. The ends of the cells are usually rounded, but they may be tapered. Nonmotile. Endospores not produced.

Deep colonies are generally smooth and compact, 0.5 to $1.0 \mathrm{~mm}$ in diameter. Nonpigmented (6).

Growth may be slow but is stimulated by the addition of 5 to $10 \% \mathrm{CO}_{2}$, Tween 80 , citrate, $\mathrm{Mn}^{2+}(4 \mathrm{mg} / \mathrm{liter})$, and thiamine (1 $\mathrm{mg} /$ liter) to complex media (1).

Calcium pantothenate, niacin, thiamine, riboflavine, and biotin are required for growth; folic acid and pyridoxal may be stimulatory (7).

Facultatively anaerobic.
Growth at 5 and $15 \mathrm{C}$; may or may not grow at $40 \mathrm{C}$; no growth at $45 \mathrm{C}$; optimum temperature, about $30 \mathrm{C}$.

Catalase negative. Benzidine negative. Nitrate not reduced. Gelatin not liquefied. No change in milk. Ammonia not produced from arginine (5-7).

Cell walls contain muramic acid. The tetrapeptide bound to muramic acid contains glucosamine, D-glutamic acid, L-lysine, and D- and L-alanine; and the cross-linking peptide bound to the $\epsilon$-amino group of L-lysine contains L-alanine and L-serine. The cell-wall composition and general structure bear marked resemblances to those of some strains of Leuconostoc (4). (5-7).

Esculin, hippurate, and starch not attacked

Heterofermentative. DL-Lactic acid and $\mathrm{CO}_{2}$ are produced from glucose. Fructose, maltose, and sucrose are also fermented. Mannose is fermented, but this property may be lost with older cultures. Polysaccharide is produced from sucrose, resulting in the production of large mucoid colonies, but old cultures may lose this property. Adonitol, amygdalin, arabinose, cellobiose, dextrin, dulcitol, erythritol, galactose, glycerol, glycogen, inositol, inulin, lactose, melibiose, melezitose, $\alpha$-methyl-D-glucoside, $\alpha$-methyl-D-mannoside, mannitol, raffinose, salicin, sorbitol, sorbose, trehalose, and xylose are not fermented (6) [specific methods cited and description expanded by Rogosa and Sharpe (7)]. Also see references 3, 5, and 6 for other general cultural and biochemical methods used.

The guanine plus cytosine content of the deoxyribonucleic acid is 37.5 moles per cent (buoyant density) (2). 


\section{LITERATURE CITED}

1. Evans, J. B., and C. F. Niven, Jr. 1951. Nutrition of the heterofermentative lactobacilli that cause greening of cured meat products. J. Bacteriol. 62:599-603.

2. Gasser, F., and M. Mandel. 1968. Deoxyribonucleic acid base composition of the genus Lactobacillus. J. Bacteriol. 96:580-588.

3. Hansen, P. A. 1968. Type strains of Lactobacillus species. A report by the taxonomic subcommittee on lactobacilli and closely related organisms. American Type Culture Collection, Rockville, Md.

4. Kandler, O., R. Plapp, and W. Holzapfel. 1967. Die Aminosäuresequenz des Serinhaltigen Mureins von Lactobacillus viridescens und Leuconostoc. Biochim. Biophys. Acta 147:252-261.

5. Niven, C. F., Jr., A. G. Castellani, and V. Allanson. 1949. A study of the lactic acid bacteria that cause surface discolorations of sausages. J. Bacteriol. 58:633-641.

6. Niven, C. F., Jr., and J. B. Evans. 1957. Lactobacillus viridescens nov spec., a heterofermentative species that produces a green discoloration of cured meat pigments. J. Bacteriol. 73:758-759.

7. Rogosa, M., and M. E. Sharpe. 1959. An approach to the classification of the lactobacilli. J. Appl. Microbiol. 22:329-340.

8. Sneath, P. H. A., and V. B. D. Skerman. 1966. A list of type and reference strains of bacteria. Int. J. Syst. Bacteriol. 16:1-133. 